\title{
IDENTIFYING THE IMPROVEMENT POSSIBILITIES OF A FLUIDIZED BED BOILER WITH EXERGY ANALYSIS
}

\author{
Mesut YAZICI ${ }^{*}$, Fatih Selim BAYRAKTAR ${ }^{2}$, Ramazan KÖSE ${ }^{3}$ \\ $1^{*}, 2$ Kütahya Dumlupınar University, Simav Faculty of Technology, Department of Energy Systems Engineering, \\ Kütahya, Turkey \\ ${ }^{3}$ Kütahya Dumlupınar University, Faculty of Engineering, Department of Mechanical Engineering, Kütahya, \\ Turkey
}

\begin{tabular}{ll}
\hline Keywords & Abstract \\
\hline $\begin{array}{l}\text { Fluidized Bed, } \\
\text { Boiler, }\end{array}$ & $\begin{array}{l}\text { In this study, a circulation-type fluidized bed boiler's exergy performance in a power } \\
\text { Exergy Efficiency, } \\
\text { Exergy Destruction. }\end{array}$ \\
dividing it into its sub-systems. In the analysis, the sub-systems' exergy performance \\
was evaluated in terms of criteria such as exergy efficiency, exergy destruction, fuel \\
depletion ratio, relative exergy destruction ratio, exergetic improvement potential, \\
and productivity lack ratio. In addition, the effect of different dead state \\
temperatures on these exergy performance criteria is compared and discussed. As a \\
result of the analysis, the highest exergy efficiency was achieved in the furnace with \\
$80.2 \%$ at $6^{\circ} \mathrm{C}$, while the highest exergy destruction occurred in the furnace as \\
$18,118.9 \mathrm{~kW}$ at $27^{\circ} \mathrm{C}$. The highest exergetic improvement potential was realized in \\
Economizer-II with $11,593.82 \mathrm{~kW}$ at $6^{\circ} \mathrm{C}$, and the lowest in Economizer-I at $27^{\circ} \mathrm{C}$ \\
with $631,9 \mathrm{~kW}$. The effect of the increase in the dead state temperature on the exergy \\
performance criteria applied to boiler sub-systems was variable. It showed its effect \\
as an increase in some sub-systems and a decrease in others.
\end{tabular}

\section{EKSERJİ ANALİİ İLE BİR AKIŞKAN YATAKLI KAZANIN IYYİLEŞTİRME OLANAKLARININ} TESPIT EDİLMESI

\begin{tabular}{l}
\hline Anahtar Kelimeler \\
\hline Akışkan Yatak, \\
Kazan, \\
Ekserji Verimi, \\
Ekserji Yıkımı.
\end{tabular}

Alıntı / Cite

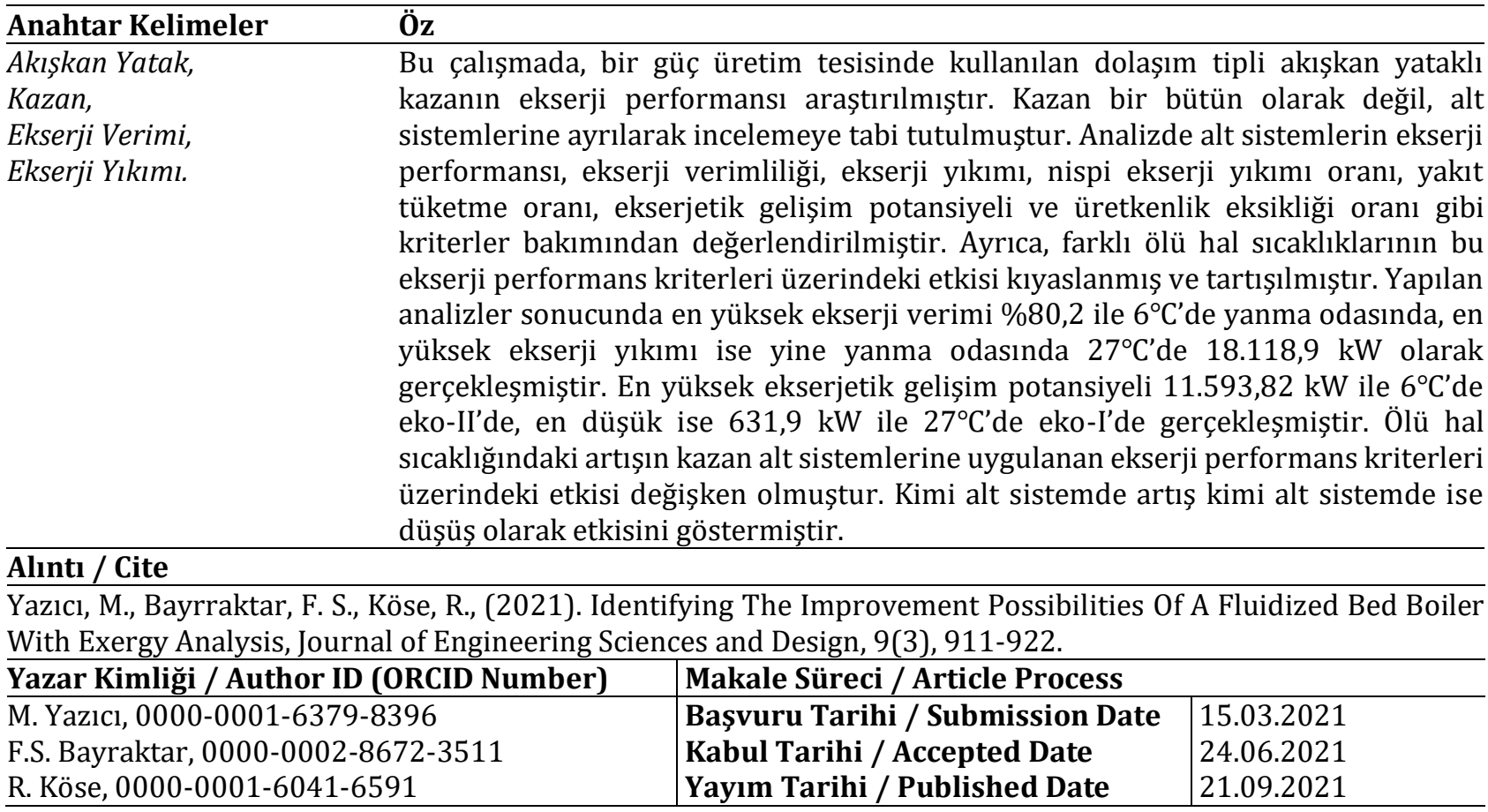

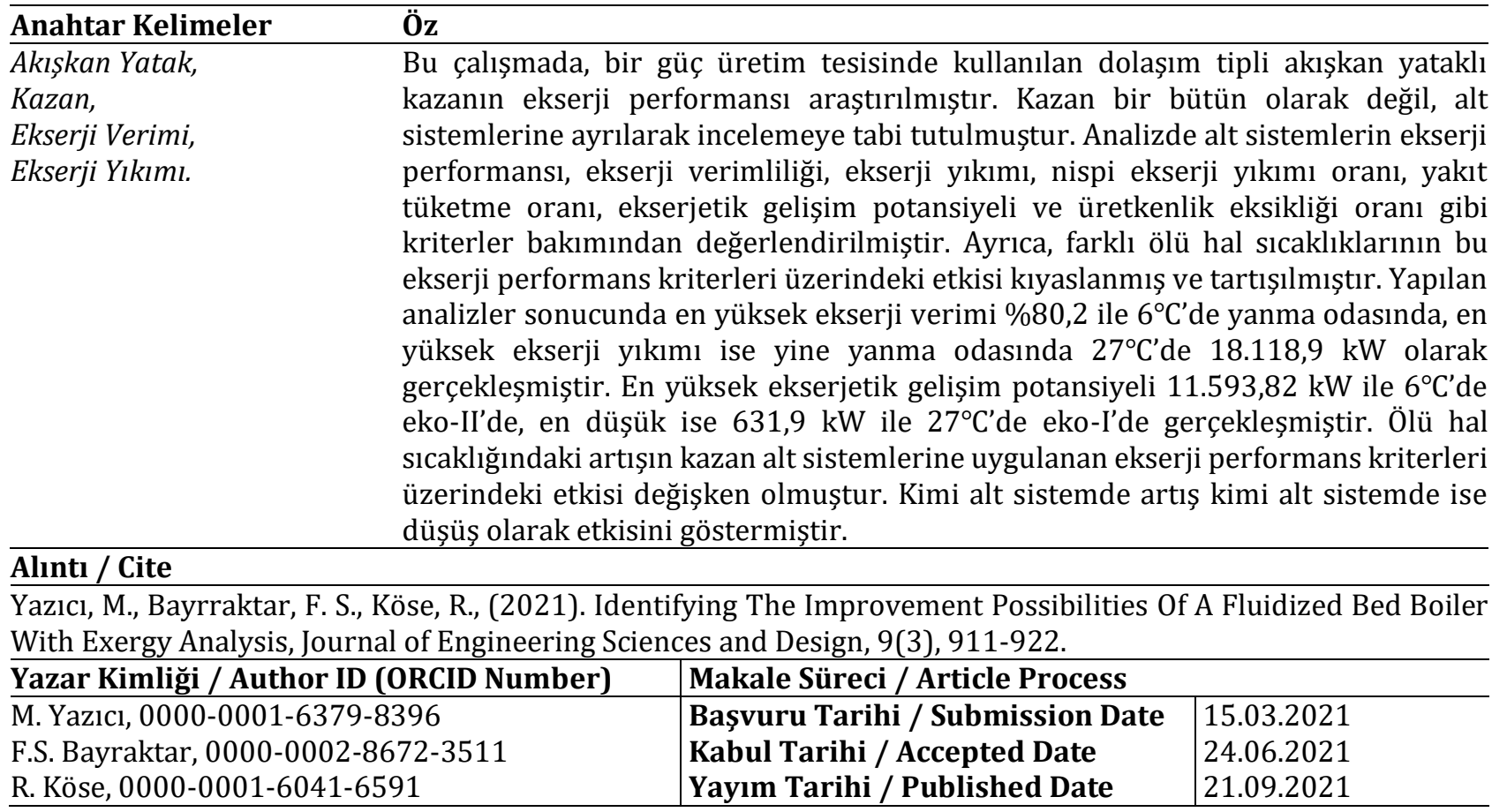

\begin{tabular}{l|l|l}
\hline Yazar Kimliği / Author ID (ORCID Number) & \multicolumn{3}{|l}{ Makale Süreci / Article Process } \\
\hline M. Yazıcı, 0000-0001-6379-8396 & Başvuru Tarihi / Submission Date & 15.03 .2021 \\
F.S. Bayraktar, 0000-0002-8672-3511 & Kabul Tarihi / Accepted Date & 24.06 .2021 \\
R. Köse, 0000-0001-6041-6591 & Yayım Tarihi / Published Date & 21.09 .2021 \\
\hline
\end{tabular}

\footnotetext{
* ilgili yazar / Corresponding author: mesut.yazici@dpu.edu.tr, +90-274-443-5082
} 


\section{Introduction}

No matter what energy source is used, power generation facilities are high-cost investments in terms of installation and operation. More investments are required to meet the increasing energy consumption in parallel with the growing population and industrialization. Beyond building new energy generation facilities, maximizing energy savings and more efficient use of energy-producing and consuming machines will constitute the strongest part of a sustainable energy policy.

In industrial plants that produce electricity or steam and both, boilers play a key role. In these facilities, the main goal is to generate more power with the same amount of fuel. For this, it is necessary to follow the annual efficiency changes of the boilers. At the same time, situations that lead to inefficiency should also be prevented. At first, the energy analysis method based on thermodynamics' first law was one of the most used tools. Although only the first law analysis is a useful tool at determining the amount of energy use, it remains helpless, especially in detecting inefficiencies and how much more existing efficiency can be improved. At this point, exergy analysis based on the second law of thermodynamics provides essential convenience. Many researchers have benefited from exergy analysis of different systems (Kolip and Savas, 2010; Akkurt and Kahraman, 2017; İpek et al., 2017; Topal et al., 2017)

In recent years, exergy analysis, which has been sought after by researchers, has become a useful diagnostic method for detecting inefficiencies in plants. With the exergy analysis, the components with high exergy destruction in the examined plants can be determined, and thus, prevention can be taken. Thermal power plants can be examined by dividing them into sub-systems, and only one component in the facility can be examined by exergy analysis. In many parts of the World, researchers have tried to demonstrate the performance of thermal power plants in operation by applying exergy analysis. Some of these are as follows; ten different power plants in Turkey (Erdem et al., 2009), 50 MW Neyveli thermal power plant (Ganapathy et al., 2009), 62.5 MW thermal power plant burning pulverized coal (Suresh et al., 2011). Li and Liu (2012) and Wu et al. (2014) applied exergy analysis in the fuel product concept to the $300 \mathrm{MW}$ thermal power plant and in component and process concept to $600 \mathrm{MW}$ thermal power plant, respectively. Wang et al. (2014) applied exergy analysis to a $600 \mathrm{MW}$ supercritical coalburning thermal power plant. Gürtürk and Oztop (2016), applied exergy analysis to a cogeneration power plant. In their study, they took the reference temperature to be $20^{\circ} \mathrm{C}(293 \mathrm{~K})$. Pattanayak and Sahu (2015) calculated and the exergy efficiency and exergy destructions of a pulverized coal fired thermal power plant in the design (500 MW) and operating conditions (460 MW). Si et al. (2017) examined the exergy efficiency, exergy loss coefficient, exergy loss ratio, and exergy distribution of a $100 \mathrm{MW}$ double re-heating ultra-supercritical thermal power plant. Also, they investigated the effect of load, feedwater temperature, main steam and reheat steam temperature and pressures on exergy efficiency. Xiong et al. (2011) compared the exergy destruction values of conventional and oxy-fired pulverized thermal power plant subcomponents. Zhou et al. (2019) conducted a comprehensive energy and exergy analysis for conventional steam power plants (TSPP) and supercritical carbon dioxide (S-CO2) power plants.

Previous studies have shown that the greatest exergy destructions in power generation facilities occurred in the boiler section. Thus, many researchers focused solely on the boiler part rather than examining the entire facility. Hepbasli (2009) created an exergetic analysis model for fluidized bed boilers and made calculations for $65 \mathrm{t} / \mathrm{h}$ steam capacity oil-shale fired boiler based on actual data. Callak et al. (2015) performed conventional and advanced exergy analysis using actual data from a fluidized bed boiler and heat recovery unit. Behbahaninia et al. (2017) proposed a new method for exergy diagnosis of steam boilers by adapting the ASME ptc 4.1 methods to exergy analysis. Thus, they estimated the exergy efficiency and exergy losses. Zhang et al. (2018) created an exergy analysis model to improve coal-fired industrial boilers' operating performance.

In addition to proving itself in detecting inefficiencies, exergy analysis is also preferred in decision-making processes and optimization processes. Several authors have made studies to question how the boilers will show their effectiveness under actual operating conditions. Sengupta et al. (2007) applied exergy analysis to a $210 \mathrm{MW}$ thermal power plant based on actual data obtained under different conditions, load, and condenser pressure as well as with and without regenerative heaters and in different turbine management settings and examined the performance change. Kopac and Hilalci (2007) applied exergy analysis to investigate ambient temperature's effect on efficiency errors and thermal power plant sub-systems' rational efficiency. Aljundi (2009) investigated the exergy efficiency and exergy destruction change of all $396 \mathrm{MW}$ thermal power plant sub-systems at different ambient temperatures. Eskin et al. (2009) applied exergy analysis to the fluidized bed boiler and sub-systems of the 7.7 MW thermal power plant. In addition, the effect of ambient temperature and excess air amount on exergy efficiency has been investigated. Regulagadda et al. (2010) conducted analyses at different operating pressures, flow rates, and temperatures to determine the parameters that maximize a $32 \mathrm{MW}$ coal-fired power plant's performance. Sharma and Singh (2016) investigated the exergy losses and efficiencies of the boiler sub-systems 
such as superheater, evaporator, and economizer in a combined cycle power plant at different dead-state conditions. Ozdil et al. (2016) investigated the effect of change in ambient temperature on the first and second law efficiency of a 6.5 MW power plant. Elhelw et al. (2019) investigated the effect of lowering condenser and IPT inlet pressure, increase in S/H steam temperature entering HPT, and increase in S/H steam temperature entering both HPT and IPT on exergy destruction, second law efficiency, and power savings. The calculations have been made for the operating conditions of the facility under full and half load conditions. Eskin and Kılıç (1996) aimed to determine the effect of cooling tubes placed at different heights of the boiler on the fluidized bed boiler's efficiency in real-time conditions and inefficiencies with exergy analysis.

Previous studies have shown that the place where exergy destruction occurs most in the electricity generation process is the boiler section, where the heat is generated. As a result, it is necessary to separate the boiler into subsystems and apply exergy analysis to each of them separately to determine in which parts and in what amount the exergy destructions occur in the boiler. Also, it will be useful to determine how much the exergy performance will be affected by the changes in actual operating conditions of the system under examination. However, previous studies have been limited. In this study, exergy analysis has been applied to a fluidized bed boiler with its subsystems. The effect of change in environmental temperature on exergy performance criteria such as exergy efficiency, exergy destruction, fuel depletion rate, relative exergy destruction, exergetic improvement potential, and productivity lack was examined. Thus, it is aimed to identify inefficient points in the boiler and to facilitate the decision-making process for improvement studies.

\section{Material and Method}

\subsection{System Description}

The system examined in this study is a circulation-type fluidized bed boiler located in a power generation facility in Kütahya, Turkey. The main use of the boiler is to provide steam for the production process. In addition, the electrical energy requirement of the machine park in the process is met by converting the steam generated in the boiler into electricity in a turbine-generator group. In this study, the boiler and its sub-systems are examined as given in Figure-1. Thus, the turbine-generator group, condenser, pumps, and other auxiliary components were not examined. Steam is produced in the boiler at a temperature of $448^{\circ} \mathrm{C}$ with a capacity of 65 tons/h. In this study, the boiler is divided into sub-systems as furnace, superheater-I, superheater-II, economizer-I, economizer-II, and air heater to detect inefficient points in the boiler.

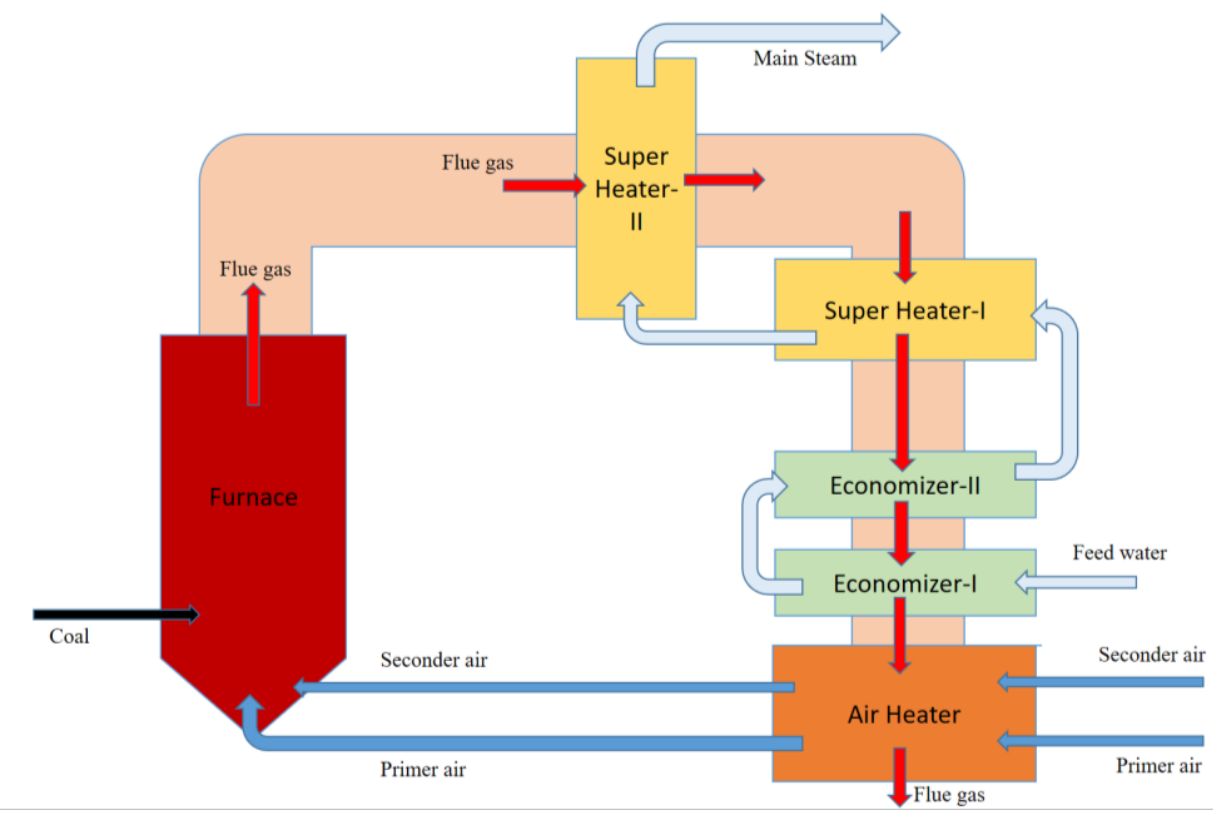

Figure 1. Simple Line Flow Chart of The Analyzed Circulation-Type Fluidized Bed Boiler

\subsection{Exergy Analysis}

In this part of the study, an exergy analysis model has been created to determine the inefficiencies in the boiler and sub-systems mentioned above. Based on the second law of thermodynamics, the concept of exergy is generally expressed as the usable part of energy. Çengel and Boles (2008) described this concept as the maximum useful work that can be obtained from the system in a certain state. 
The exergy analysis of the system examined in this study was carried out under steady-state conditions. The boiler was analyzed not as a whole but divided into its sub-systems. Each of the boiler sub-systems is considered as a control volume. Pressure and exergy losses in piping systems are not taken into account. The dead state conditions are taken as the temperature $25^{\circ} \mathrm{C}$ and the pressure as $101.325 \mathrm{kPa}$. However, to observe the change in the boiler's exergy performance according to the actual environmental conditions, the dead state temperature value was based on the seasonal temperature averages of Kütahya. According to this, the dead state temperature values were accepted as $6^{\circ} \mathrm{C}, 16^{\circ} \mathrm{C}, 19^{\circ} \mathrm{C}$ and $27^{\circ} \mathrm{C}$ for the winter, autumn, spring and summer seasons, respectively.

Exergy balances should be established in order to determine the exergy efficiency and exergy destruction values of the boiler sub-systems. First of all, the incoming and outgoing flows were determined for each of these subsystems, and nodal points were formed. The total specific exergy value for each node is calculated using Equation 1.

$$
e x_{t}=e x_{p}+e x_{c h}+e x_{k n}+e x_{p t}
$$

where ext is total specific exergy, exp is physical exergy, ex $x_{c h}$ is chemical exergy, ex $\mathrm{kn}_{\mathrm{k}}$ is kinetic exergy, and expt is potential exergy. The kinetic and potential exergy values at the nodes of the sub-systems determined in the boiler have been neglected since they remain low enough not to change the result. The overall flow exergy was calculated using the following equation,

$$
e x_{p}=\left(h-h_{0}\right)-T_{0}\left(s-s_{0}\right)
$$

In this study, Equation 3 is used to calculate the physical exergy value of air, which is considered as the ideal gas,

$$
\operatorname{ex}_{p, \text { air }}=\left[c_{p}\left(T-T_{0}-T_{0} \ln \frac{T}{T_{0}}\right)+R T_{0} \ln \frac{P}{P_{0}}\right]
$$

where $\mathrm{R}$ is the ideal gas constant of air, $\mathrm{c}_{\mathrm{p}}$ is the specific heat of air, $\mathrm{T}$ is temperature, and $\mathrm{P}$ is pressure. The index 0 expresses the value in the dead state for temperature and pressure. Chemical exergy calculation of flue gas on a molar basis,

$$
\bar{e} x_{c h}=\sum x_{k} \bar{e}_{k}^{c h}+\bar{R} T_{0} \sum x_{k} \ln x_{k}
$$

In the equation given above, $\mathrm{x}_{\mathrm{k}}$ is the molar fraction, $\bar{e}_{k}^{c h}$ standard molar chemical exergy of the flue gas components, and $\bar{R}$ is the universal gas constant. The physical exergy of burning the solid coal fuel in the boiler has been neglected because it is very low compared to its chemical exergy. Szargut's chemical exergy equation of coal was used to calculate coal's chemical exergy (Szargut, 2005).

$$
\begin{aligned}
& e x_{c h}=\varphi(L H V) \\
& \varphi=1.0437+0.1896(h / c)+0.2499(o / c)+0.0428(n / c)(6)
\end{aligned}
$$

LHV represents the lower calorific value of the fuel, h, c, o, and n denotes the fuel elements' ratio, and $\varphi$ represents the chemical exergy factor. General exergy balance and exergy efficiency expressions are derived for the boiler sub-systems. The equations created are given in Table 1. With these equations' help, each sub-system of the boiler's exergy efficiency and exergy destructions are determined. In addition to these exergy performance evaluation criteria, fuel depletion rate, relative exergy destruction rate, and productivity lack rate criteria were also investigated (Xiang et al., 2004; Balli et al., 2008; Şöhret et al., 2015).

$$
\delta_{k}=\frac{\dot{E} x_{D, k}}{\dot{E} x_{\text {fuel, }, \text { total }}}
$$




$$
\begin{aligned}
& \chi_{k}=\frac{\dot{E} x_{D, k}}{\dot{E} x_{D, \text { Total }}} \\
& \zeta_{k}=\frac{\dot{E} x_{D, k}}{\dot{E} x_{\text {product }, \text { total }}}
\end{aligned}
$$

Van Gool (1992) proposed the exergetic improvement potential method to demonstrate how the system's performance can be further improved. Dincer and Rosen (2007) applied the exergy improvement potential method for coal fired power plants.

$$
\dot{P}_{k}=\left(1-\eta_{\text {ex, }}\right)\left(\dot{E} x_{\text {in }}-\dot{E} x_{\text {out }}\right)
$$

Table 1. General Exergy Balance and Exergy Efficiency Equations of Boiler Sub-Systems

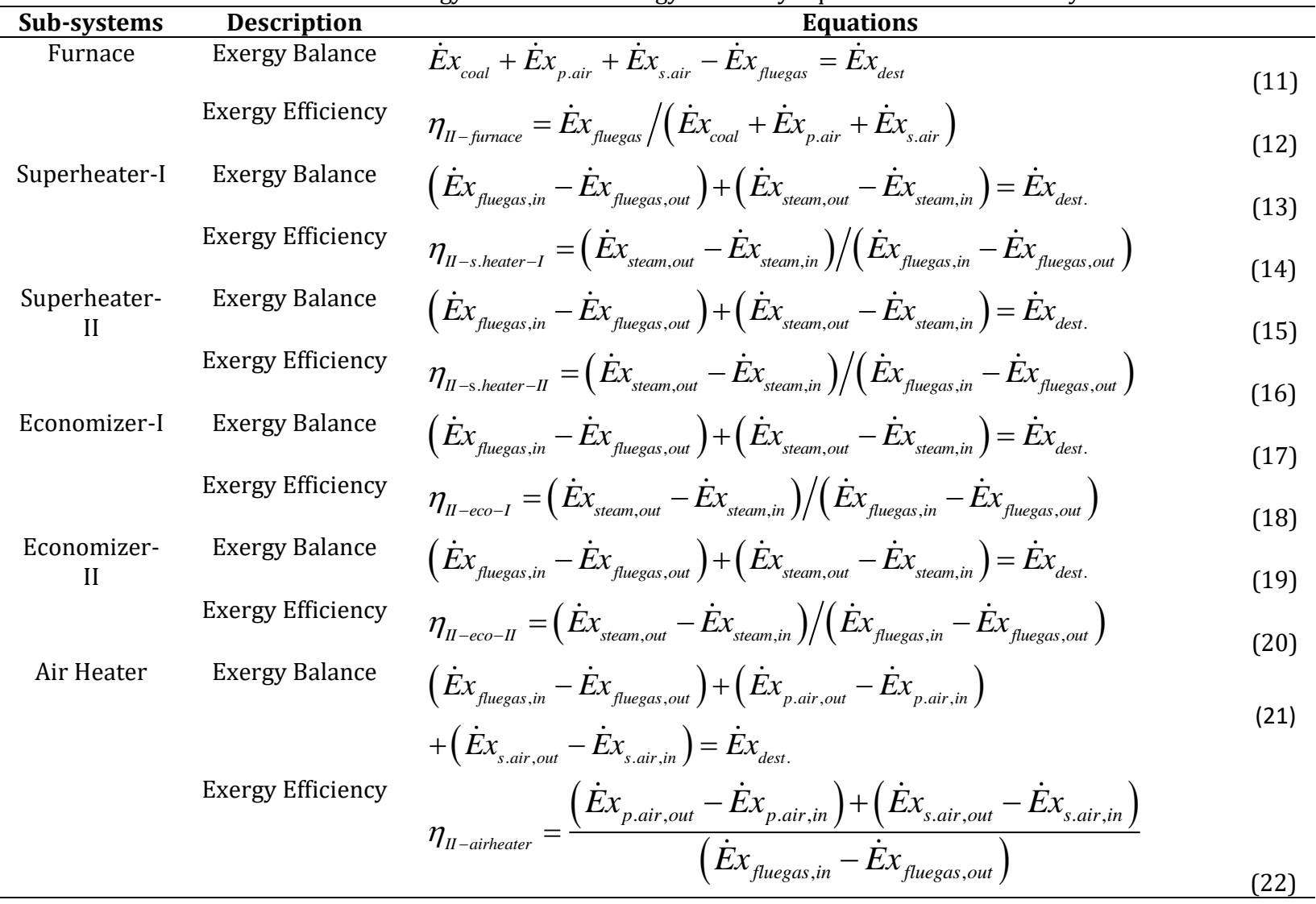

\section{Results and Discussions}

In this section, the calculation results made by applying real data to the exergy analysis model created for the subsystems of the fluidized bed boiler are given and discussed. Actual data used in the calculations are taken from the boiler control-automation system. Some of the values obtained are as given in Table 2 . Coal burned in the boiler is produced in Kütahya Tunçbilek, Turkey. Coal is fed into the combustion chamber at a flow rate of $3.1 \mathrm{~kg} / \mathrm{s}$ and burned. Elemental analysis values of coal are as given in Table 3 (Yazıcı and Köse, 2019). According to this, the lower calorific value of the fired coal is $5169 \mathrm{kcal} / \mathrm{kg}$. Coal contains $11.8 \%$ moisture, $1.04 \%$ sulfur and $55.2 \%$ carbon. By placing the data given in Table 3 into Equation 5 and Equation 6, the exergy of coal was calculated as $72,568.055 \mathrm{~kW}$. Besides, the primary combustion air at $205^{\circ} \mathrm{C}$ and the secondary combustion air at $193^{\circ} \mathrm{C}$ heated in the air heater enter the combustion chamber from different levels. The steam entering the economizer-I at $115^{\circ} \mathrm{C}$ circulates through the economizer-II, superheater-I, and finally exits the superheater-II as steam at $448^{\circ} \mathrm{C}$ at $18.06 \mathrm{~kg} / \mathrm{s}$. 
Table 2. Some Thermodynamic Values of System Components

\begin{tabular}{|c|c|c|c|}
\hline Items & Value & Items & Value \\
\hline \multicolumn{4}{|l|}{ Furnace } \\
\hline The mass flow rate of coal & $3,1 \mathrm{~kg} / \mathrm{s}$ & The temperature of seconder air & $193^{\circ} \mathrm{C}$ \\
\hline Mass flow rate of primer air & $13,9 \mathrm{~kg} / \mathrm{s}$ & Mass flow rate of flue gas & $18,6 \mathrm{~kg} / \mathrm{s}$ \\
\hline The temperature of primer air & $205^{\circ} \mathrm{C}$ & The outlet temperature of flue gas & $840^{\circ} \mathrm{C}$ \\
\hline $\begin{array}{c}\text { The mass flow rate of seconder air } \\
\text { Air Heater }\end{array}$ & $6,3 \mathrm{~kg} / \mathrm{s}$ & & \\
\hline The mass flow rate of primer air & $13,9 \mathrm{~kg} / \mathrm{s}$ & The outlet temperature of seconder air & $193^{\circ} \mathrm{C}$ \\
\hline The inlet temperature of primer air & $35^{\circ} \mathrm{C}$ & The mass flow rate of flue gas & $18,6 \mathrm{~kg} / \mathrm{s}$ \\
\hline The outlet temperature of primer air & $205^{\circ} \mathrm{C}$ & The inlet temperature of flue gas & $280^{\circ} \mathrm{C}$ \\
\hline The mass flow rate of seconder air & $6,3 \mathrm{~kg} / \mathrm{s}$ & The outlet temperature of flue gas & $195^{\circ} \mathrm{C}$ \\
\hline $\begin{array}{l}\text { The inlet temperature of seconder air } \\
\text { Super heater-I }\end{array}$ & $30^{\circ} \mathrm{C}$ & & \\
\hline Mass flow rate of flue gas & $18,6 \mathrm{~kg} / \mathrm{s}$ & Mass flow rate of steam & $18,06 \mathrm{~kg} / \mathrm{s}$ \\
\hline The inlet temperature of flue gas & $690^{\circ} \mathrm{C}$ & The inlet temperature of the steam & $226^{\circ} \mathrm{C}$ \\
\hline $\begin{array}{l}\text { The outlet temperature of flue gas } \\
\text { Super heater-II }\end{array}$ & $600^{\circ} \mathrm{C}$ & The outlet temperature of the steam & $352^{\circ} \mathrm{C}$ \\
\hline Mass flow rate of flue gas & $18,6 \mathrm{~kg} / \mathrm{s}$ & Mass flow rate of steam & $18,06 \mathrm{~kg} / \mathrm{s}$ \\
\hline The inlet temperature of flue gas & $760^{\circ} \mathrm{C}$ & The inlet temperature of the steam & $336^{\circ} \mathrm{C}$ \\
\hline $\begin{array}{l}\text { The outlet temperature of flue gas } \\
\text { Economizer-I }\end{array}$ & $690^{\circ} \mathrm{C}$ & The outlet temperature of the steam & $448^{\circ} \mathrm{C}$ \\
\hline Mass flow rate of flue gas & $18,6 \mathrm{~kg} / \mathrm{s}$ & Mass flow rate of steam & $18,06 \mathrm{~kg} / \mathrm{s}$ \\
\hline The inlet temperature of flue gas & $380^{\circ} \mathrm{C}$ & The inlet temperature of the steam & $115^{\circ} \mathrm{C}$ \\
\hline $\begin{array}{l}\text { The outlet temperature of flue gas } \\
\text { Economizer-II }\end{array}$ & $280^{\circ} \mathrm{C}$ & Economizer-II & $158^{\circ} \mathrm{C}$ \\
\hline Mass flow rate of flue gas & $18,6 \mathrm{~kg} / \mathrm{s}$ & Mass flow rate of steam & $18,06 \mathrm{~kg} / \mathrm{s}$ \\
\hline The inlet temperature of flue gas & $600^{\circ} \mathrm{C}$ & The inlet temperature of the steam & $158^{\circ} \mathrm{C}$ \\
\hline The outlet temperature of flue gas & $380^{\circ} \mathrm{C}$ & The outlet temperature of the steam & $230^{\circ} \mathrm{C}$ \\
\hline
\end{tabular}

Table 3. Coal's Analysis Values

\begin{tabular}{ccc}
\hline Items & Unit & Value \\
\hline $\mathrm{C}$ & $(\%)$ & 55,2 \\
$\mathrm{H}_{2}$ & $(\%)$ & 3,94 \\
$\mathrm{O}_{2}$ & $(\%)$ & 6,36 \\
$\mathrm{~N}_{2}$ & $(\%)$ & 2,08 \\
$\mathrm{~S}_{2}$ & $(\%)$ & 1,04 \\
Moisture & $(\%)$ & 11,81 \\
Lower Heating Value & $(\mathrm{kcal} / \mathrm{kg})$ & 5149 \\
Higher Heating Value & $(\mathrm{kcal} / \mathrm{kg})$ & 5408 \\
\hline
\end{tabular}

Flue gas measurements were made with a flue gas analyzer before the electrostatic filter (ESP). Measurement values are given in Table $4 . \mathrm{SO}_{2}$ at a rate of $0.18 \%$, $\mathrm{CO}$ at a rate of $0.02 \%$, and $\mathrm{O}_{2}$ at a rate of $3.9 \%$ were detected in the flue gas. In addition to these, there is $15.2 \% \mathrm{CO}_{2}$ and $80.7 \% \mathrm{~N}_{2}$. Mass flow rate, molar flow rate, and molar fractions were calculated for each of the components that make up the flue gas using the percentage ratios.

Table 4. Measurement Values of Flue Gas

\begin{tabular}{ccccccc}
\hline $\begin{array}{c}\text { Combustion } \\
\text { Gaseous }\end{array}$ & Mass Fraction & $\begin{array}{c}\text { Mass flow } \\
\text { rates } \\
\mathbf{( k g / s )}\end{array}$ & $\begin{array}{c}\text { Molar mass } \\
\mathbf{( k g / k m o l )}\end{array}$ & $\begin{array}{c}\text { Molar flow } \\
\text { rates } \\
\text { (kmol/s) }\end{array}$ & $\begin{array}{c}\text { Molar } \\
\text { fractions }\end{array}$ & $\begin{array}{c}\text { Standard } \\
\text { chemical } \\
\text { exergy } \\
\text { (Szargut et } \\
\text { al., 1988) }\end{array}$ \\
\hline $\mathrm{O}_{2}$ & & & & & & 3970 \\
$\mathrm{CO}_{2}$ & 0,039 & 0,7137 & 31,99 & 0,0223 & 0,036365 & 21140 \\
$\mathrm{CO}$ & 0,152 & 2,7816 & 44,01 & 0,0632 & 0,103049 & 275430 \\
$\mathrm{SO}_{2}$ & 0,0002 & 0,00366 & 28,011 & 0,0001 & 0,000213 & 303500 \\
$\mathrm{~N}_{2}$ & 0,0018 & 0,03294 & 64,063 & 0,0005 & 0,000838 & 720 \\
\hline \hline
\end{tabular}

Exergy efficiency values of the boiler sub-systems were calculated according to the seasonal temperature averages of Kütahya. As shown in Table 5, the ambient temperature change caused significant changes in some sub-systems' exergy efficiency, while minimal change occurred in others. The highest exergy efficiency was obtained in the combustion chamber at $6^{\circ} \mathrm{C}$ ambient conditions. While the superheater-I's exergy efficiency increased in parallel with the increase in the ambient temperature, there was a decrease in the superheater-II's exergy efficiency. There was a $0.3 \%$ increase in the efficiency of superheater-I and a $1 \%$ decrease in superheater-II. The exergy efficiency 
of the furnace decreased from $80.2 \%$ at $6^{\circ} \mathrm{C}$ to $75.4 \%$ at $27^{\circ} \mathrm{C}$. The decrease occurring here is due to the effect of the post-combustion gases from the increase in ambient temperature. The exergy of fuel burned remains constant at all temperature values. Unlike other sub-systems, there was an increase in exergy efficiency in economizer-I and economizer-II I parallel with the rise in ambient temperature.

Table 5. Exergy Efficiencies Values of Boiler Sub-Systems at Different Ambient Temperature Conditions

\begin{tabular}{cccccc}
\hline Sub-systems & $\mathbf{6}^{\circ} \mathbf{C}$ & $\mathbf{1 6}^{\circ} \mathbf{C}$ & $\mathbf{1 9}^{\circ} \mathbf{C}$ & $\mathbf{2 5}^{\circ} \mathbf{C}$ & $\mathbf{2 7}^{\circ} \mathbf{C}$ \\
\hline Furnace & 80,2 & 77,8 & 77,2 & 75,8 & 75,4 \\
S-Heater-II & 41,4 & 40,9 & 40,8 & 40,5 & 40,4 \\
S-Heater-I & 43,6 & 43,7 & 43,8 & 43,9 & 43,9 \\
Economizer-II & 20,1 & 21,2 & 21,5 & 22,1 & 22,3 \\
Economizer-I & 60,1 & 63,7 & 64,8 & 67,1 & 67,9 \\
Air Heater & 21,5 & 20,4 & 20,1 & 19,3 & 18,9 \\
\hline
\end{tabular}

In order to increase efficiency by making improvements in the examined systems, it is necessary to determine the parts where exergy destruction occurs. In this study, the amount of exergy destruction occurring in the boiler subsystems at different dead state temperature values was calculated. Calculated values are given in Table 6 . At the ambient temperature increasing from $6^{\circ} \mathrm{C}$ to $27^{\circ} \mathrm{C}$, exergy destruction values increased at the combustion rate, while the superheater-I, superheater-II, economizer-I, economizer-II, and air heater decreased. The total exergy destruction in the boiler increased with the increase in the dead state temperature. The highest exergy destruction value occurred at $27^{\circ} \mathrm{C}$ in the furnace. While the highest exergy destruction at $25^{\circ} \mathrm{C}$ was $17,796.6 \mathrm{~kW}$ in the furnace, the second-highest destruction happened in the economizer-II with 13,530.8 kW. The lowest exergy destruction was in economizer-I with $2031.1 \mathrm{~kW}$.

Table 6. Exergy Destructions Values of Boiler Sub-Systems at Different Environment Temperature Conditions

\begin{tabular}{cccccc}
\hline Sub-systems & $\mathbf{6}^{\circ} \mathbf{C}$ & $\mathbf{1 6}^{\circ} \mathbf{C}$ & $\mathbf{1 9}^{\circ} \mathbf{C}$ & $\mathbf{2 5}^{\circ} \mathbf{C}$ & $\mathbf{2 7}^{\circ} \mathbf{C}$ \\
\hline Furnace & 14619,4 & 16308,5 & 16807,9 & 17796,6 & 18118,9 \\
S-Heater-II & 4078,2 & 4045,5 & 4035,8 & 4016,5 & 4010,1 \\
S-Heater-I & 4807,04 & 4709 & 4679,7 & 4621,3 & 4601,8 \\
Economizer-II & 14512,2 & 13984,71 & 13839,9 & 13530,8 & 13428 \\
Economizer-I & 2630,7 & 2314,5 & 2219,9 & 2031,1 & 1968,4 \\
Air Heater & 3499,5 & 3386,2 & 3352,5 & 3285,1 & 3267,1 \\
\hline Total & $\mathbf{4 4 . 1 4 7 , 0 4}$ & $\mathbf{4 4 . 7 4 8 , 4 1}$ & $\mathbf{4 4 . 9 3 5 , 7}$ & $\mathbf{4 5 . 2 8 1 , 4}$ & $\mathbf{4 5 . 3 9 4 , 3}$ \\
\hline
\end{tabular}

The fuel depletion rate, relative exergy destruction rate, exergetic improvement potential value, and productivity lack were calculated and compared for each fluidized bed boiler sub-system. The results of these calculated exergy performance evaluation criteria are given in Table 7 , Table 8, Table 9 Table 10 and Table 11 for $6^{\circ} \mathrm{C}, 16^{\circ} \mathrm{C}, 19^{\circ} \mathrm{C}$, $25^{\circ} \mathrm{C}$ and $27^{\circ} \mathrm{C}$, respectively. When these given tables are examined, the best value in terms of relative exergy destruction rate, fuel depletion rate, and productivity lack rate criteria was determined in economizer-I, and the best value for exergetic development potential was determined in economizer-II. In terms of relative exergy destruction rate, fuel depletion rate, and productivity lack rate, the worst value was determined in the furnace and economizer-II, and the worst value was determined in economizer-I for exergetic improvement potential. Within the framework of these results, in case of improvement work for boiler sub-systems, priority should be given to the economizer-II and then to the combustion chamber. In particular, $10,537.8 \mathrm{~kW}(77.9 \%)$ of the exergy destruction of $13,530.8 \mathrm{~kW}$ in economizer-II at $25^{\circ} \mathrm{C}$ can be improved.

Table 7. Exergy Performance Values of Boiler Sub-Systems At $6^{\circ} \mathrm{C}$ Ambient Temperature Condition

\begin{tabular}{ccccc}
\hline Sub-systems & $\boldsymbol{\delta} \mathbf{( \% )}$ & $\boldsymbol{\chi} \mathbf{( \% )}$ & $\mathbf{I P}_{\mathbf{k}} \mathbf{( k W )}$ & $\boldsymbol{\zeta ( \% )}$ \\
\hline Furnace & 12,3 & 33,1 & 2897,75 & 19,6 \\
S-Heater-II & 3,4 & 9,2 & 2390,58 & 5,5 \\
S-Heater-I & 4,06 & 10,9 & 2712,79 & 6,5 \\
Economizer-II & 12,2 & 32,8 & 11593,8 & 19,5 \\
Economizer-I & 2,2 & 5,9 & 1049,7 & 3,5 \\
Air Heater & 2,9 & 7,9 & 2746,45 & 4,71 \\
\hline
\end{tabular}

Table 8. Exergy Performance Values of Boiler Sub-Systems at $16^{\circ} \mathrm{C}$ Ambient Temperature Condition

\begin{tabular}{ccccc}
\hline Sub-systems & $\boldsymbol{\delta} \mathbf{( \% )}$ & $\boldsymbol{\chi} \mathbf{( \% )}$ & $\mathbf{I P}_{\mathbf{k}} \mathbf{( k W )}$ & $\boldsymbol{\zeta ( \% )}$ \\
\hline Furnace & 13,9 & 36,4 & 3610,9 & 22,5 \\
S-Heater-II & 3,4 & 9,04 & 2389,7 & 5,6 \\
S-Heater-I & 4,01 & 10,5 & 2649,6 & 6,5 \\
Economizer-II & 11,9 & 31,2 & 11019,4 & 19,3 \\
Economizer-I & 1,9 & 5,2 & 840,7 & 3,2 \\
Air Heater & 2,9 & 7,5 & 2695,3 & 4,7
\end{tabular}


Table 9. Exergy Performance Values of Boiler Sub-Systems at $19^{\circ} \mathrm{C}$ Ambient Temperature Condition

\begin{tabular}{ccccc}
\hline Sub-systems & $\boldsymbol{\delta} \mathbf{( \% )}$ & $\boldsymbol{\chi} \mathbf{( \% )}$ & $\mathbf{I P}_{\mathbf{k}} \mathbf{( k W )}$ & $\boldsymbol{\zeta} \mathbf{( \% )}$ \\
\hline Furnace & 14,4 & 37,4 & 3836,9 & 23,3 \\
S-Heater-II & 3,45 & 8,9 & 2389,5 & 5,6 \\
S-Heater-I & 4 & 10,4 & 2630,7 & 6,5 \\
Economizer-II & 11,8 & 30,8 & 10868,9 & 19,2 \\
Economizer-I & 1,8 & 4,9 & 781,5 & 3,1 \\
Air Heater & 2,86 & 7,4 & 2680,4 & 4,65 \\
\hline
\end{tabular}

Table 10. Exergy Performance Values of Boiler Sub-Systems at $25^{\circ} \mathrm{C}$ Ambient Temperature Condition

\begin{tabular}{ccccc}
\hline Sub-systems & $\boldsymbol{\delta} \mathbf{( \% )}$ & $\boldsymbol{\chi} \mathbf{( \% )}$ & $\mathbf{I P}_{\mathbf{k}} \mathbf{( k W )}$ & $\boldsymbol{\zeta} \mathbf{( \% )}$ \\
\hline Furnace & 15,3 & 39,3 & 4304,8 & 25,1 \\
S-Heater-II & 3,4 & 8,9 & 2389,5 & 5,6 \\
S-Heater-I & 3,9 & 10,2 & 2593,2 & 6,5 \\
Economizer-II & 11,6 & 29,9 & 10537,8 & 19,1 \\
Economizer-I & 1,7 & 4,5 & 668,1 & 2,8 \\
Air Heater & 2,8 & 7,2 & 2650,9 & 4,6 \\
\hline
\end{tabular}

Table 11. Exergy Performance Values of Boiler Sub-Systems at $27^{\circ} \mathrm{C}$ Ambient Temperature Condition

\begin{tabular}{ccccc}
\hline Sub-systems & $\boldsymbol{\delta} \mathbf{( \% )}$ & $\boldsymbol{\chi ( \% )}$ & $\left.\mathbf{I P}_{\mathbf{k}} \mathbf{( k W}\right)$ & $\boldsymbol{\zeta ( \% )}$ \\
\hline Furnace & 15,6 & 40 & 4463,5 & 25,7 \\
S-Heater-II & 3,4 & 8,8 & 2389,5 & 5,7 \\
S-Heater-I & 3,9 & 10,1 & 2580,7 & 6,5 \\
Economizer-II & 11,6 & 29,6 & 10427,9 & 19 \\
Economizer-I & 1,7 & 4,3 & 631,9 & 2,8 \\
Air Heater & 2,8 & 7,2 & 2648,4 & 4,6 \\
\hline
\end{tabular}

After calculating the exergy destruction values in the boiler sub-systems according to different ambient temperatures, the specific exergy destruction rates were compared. As given in Figure 2, the furnace and economizer-II have the highest relative exergy destruction rate. The increase in the dead state temperature only increased the relative exergy destruction rate of the furnace. It was found that there was a decrease in other parts. While $33.1 \%$ of the exergy destruction occurring in the entire boiler at $6^{\circ} \mathrm{C}$ occurs in the furnace when the ambient temperature rises to $27^{\circ} \mathrm{C}$, the ratio increases to $39.9 \%$. In economizer-II, it decreased from $32.8 \%$ to $29.6 \%$ in the same temperature range. In other parts, minimal amounts of change were experienced.

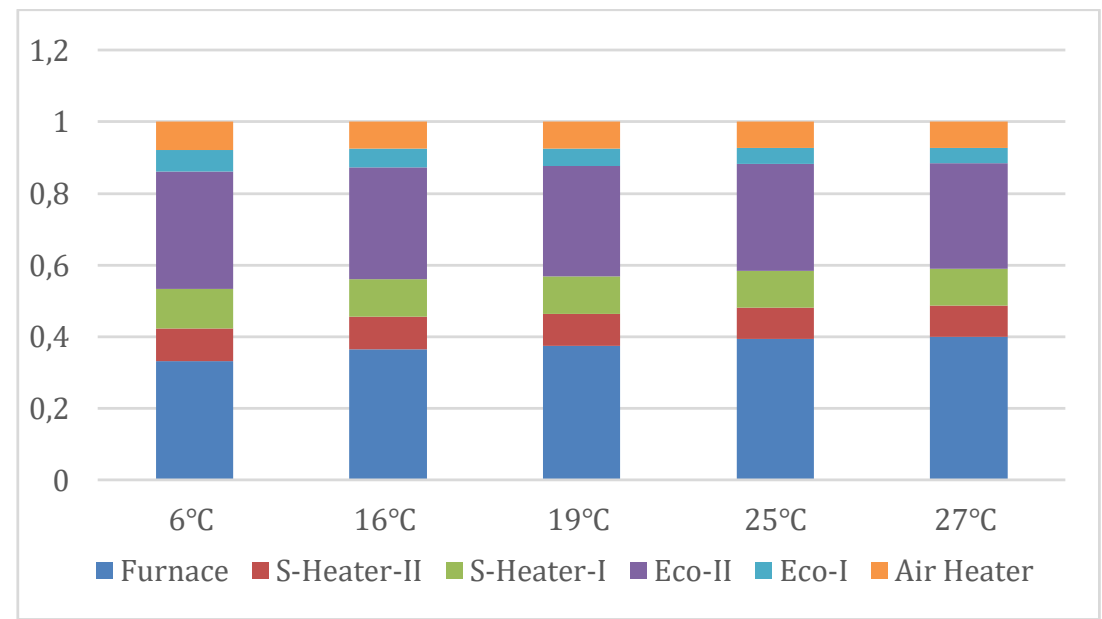

Figure 2. Relative Exergy Destruction of Boiler Sub-Systems at Different Ambient Temperatures

The variation of exergetic improvement potentials of boiler sub-systems at different ambient temperatures is given in Figure 3. The highest exergetic development potential was realized as $11,593.8 \mathrm{~kW}$ at $6^{\circ} \mathrm{C}$ in economizerII. The lowest value was $631.9 \mathrm{~kW}$ in economizer-I at $27^{\circ} \mathrm{C}$. As with the specific exergy destruction rate in the boiler sub-systems, the ambient temperature increase had a similar effect on all sub-systems' exergetic development potential value. Although the highest potential was in economizer-II, the highest rate of change occurred in the combustion chamber. This value, which was $2897.7 \mathrm{~kW}$ at $6^{\circ} \mathrm{C}$, rose to $4463.5 \mathrm{~kW}$ with an increase of $54 \%$ when it came to $27^{\circ} \mathrm{C}$.

Figure 4 and Figure 5 show the productivity lack and fuel depletion rates of the boiler sub-systems at different temperatures, respectively. Depending on the increase in the ambient temperature, the productivity lack ate, and the fuel consumption rate for the furnace and superheater-II of the boiler sub-systems increased, while only the 
productivity lack rate increased in the superheater-I. In other parts, on the contrary, there was a decrease. For both criteria, the furnace was mainly affected by the change in the ambient temperature. Thus, the productivity lack rate increased from $19.7 \%$ at $6^{\circ} \mathrm{C}$ to $25.7 \%$ at $27^{\circ} \mathrm{C}$. Likewise, the fuel depletion ratio increased from $12.3 \%$ at $6^{\circ} \mathrm{C}$ to $15.6 \%$ at $27^{\circ} \mathrm{C}$. Except for the combustion chamber, there was a reduction of $1 / 5$ in productivity lack and $1 / 4$ in fuel consumption ratio in the same temperature range in economizer-I. In other parts, the change occurred at very low rates.

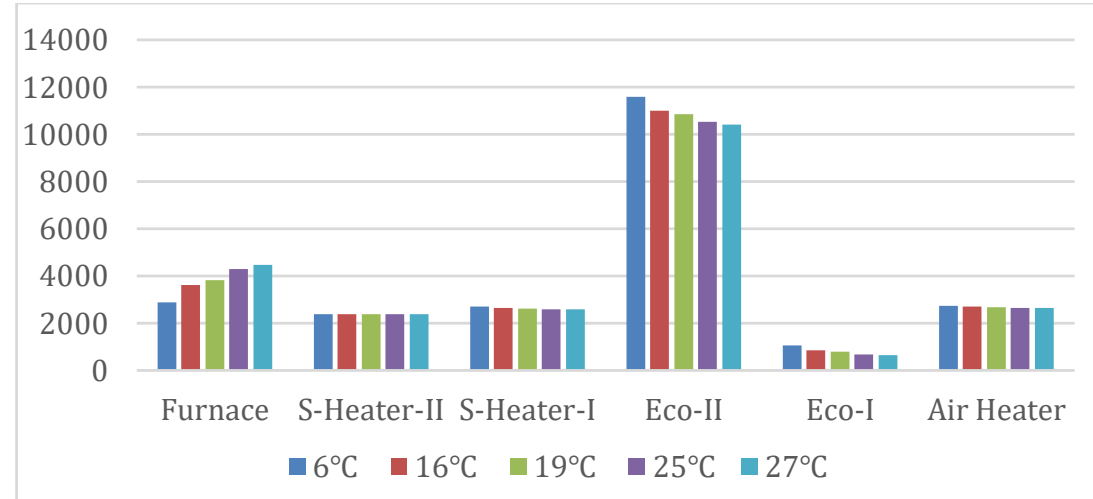

Figure 3. Exergetic Improvement Potential of Boiler Sub-Systems at Different Ambient Temperatures

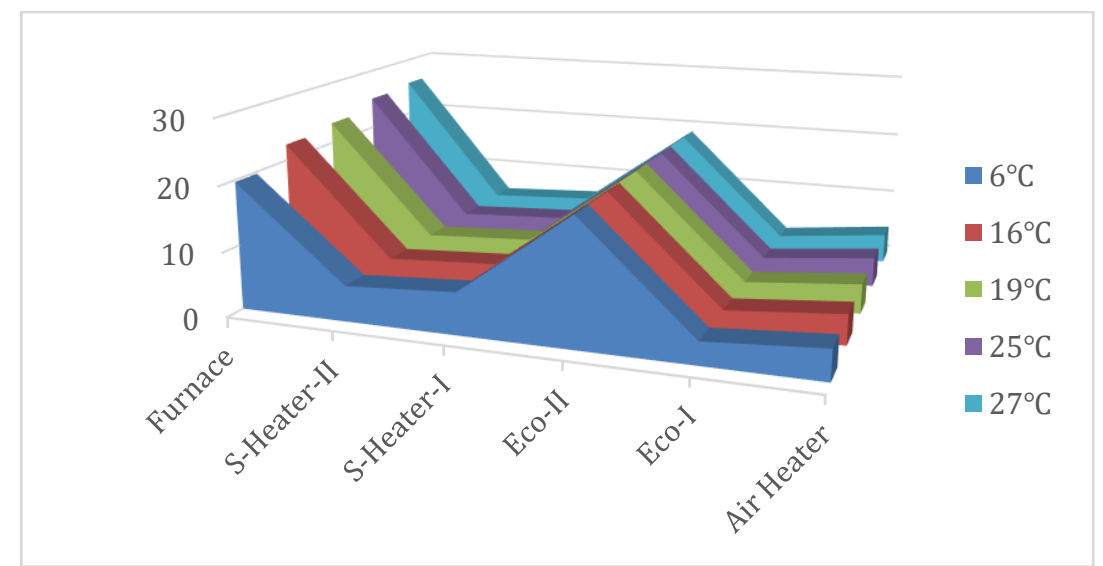

Figure 4. Productivity Lack of Boiler Sub-Systems at Different Ambient Temperatures

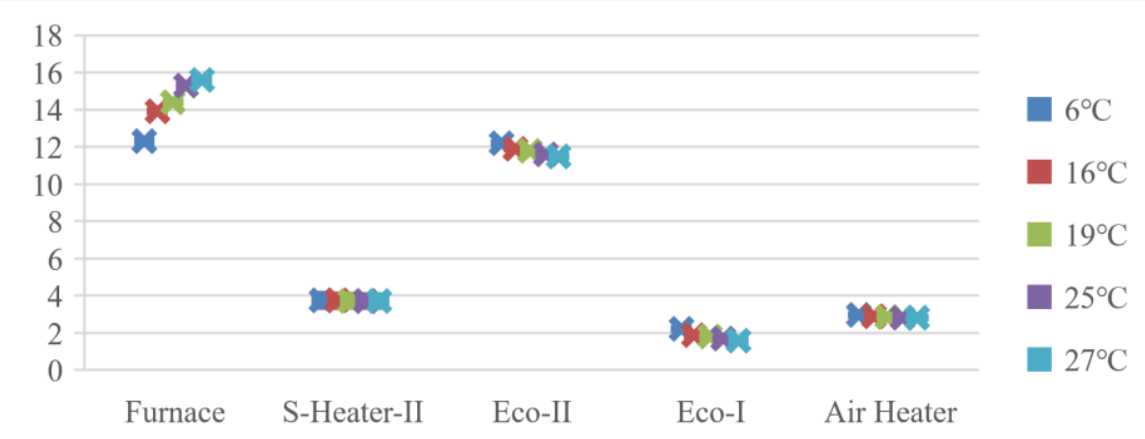

Figure 5. The Fuel Depletion Rate of Boiler Sub-Systems at Different Ambient Temperatures

Figure 6 simply shows the exergy flow in boiler sub-systems at $25^{\circ} \mathrm{C}$. Accordingly, the $72,568.055 \mathrm{~kW}$ exergy obtained from the coal burned in the combustion chamber is utilized in the boiler's other sub-systems and is destroyed and eventually leaves the $5139.8 \mathrm{~kW}$ exergy boiler as flue gas from the air heater. 


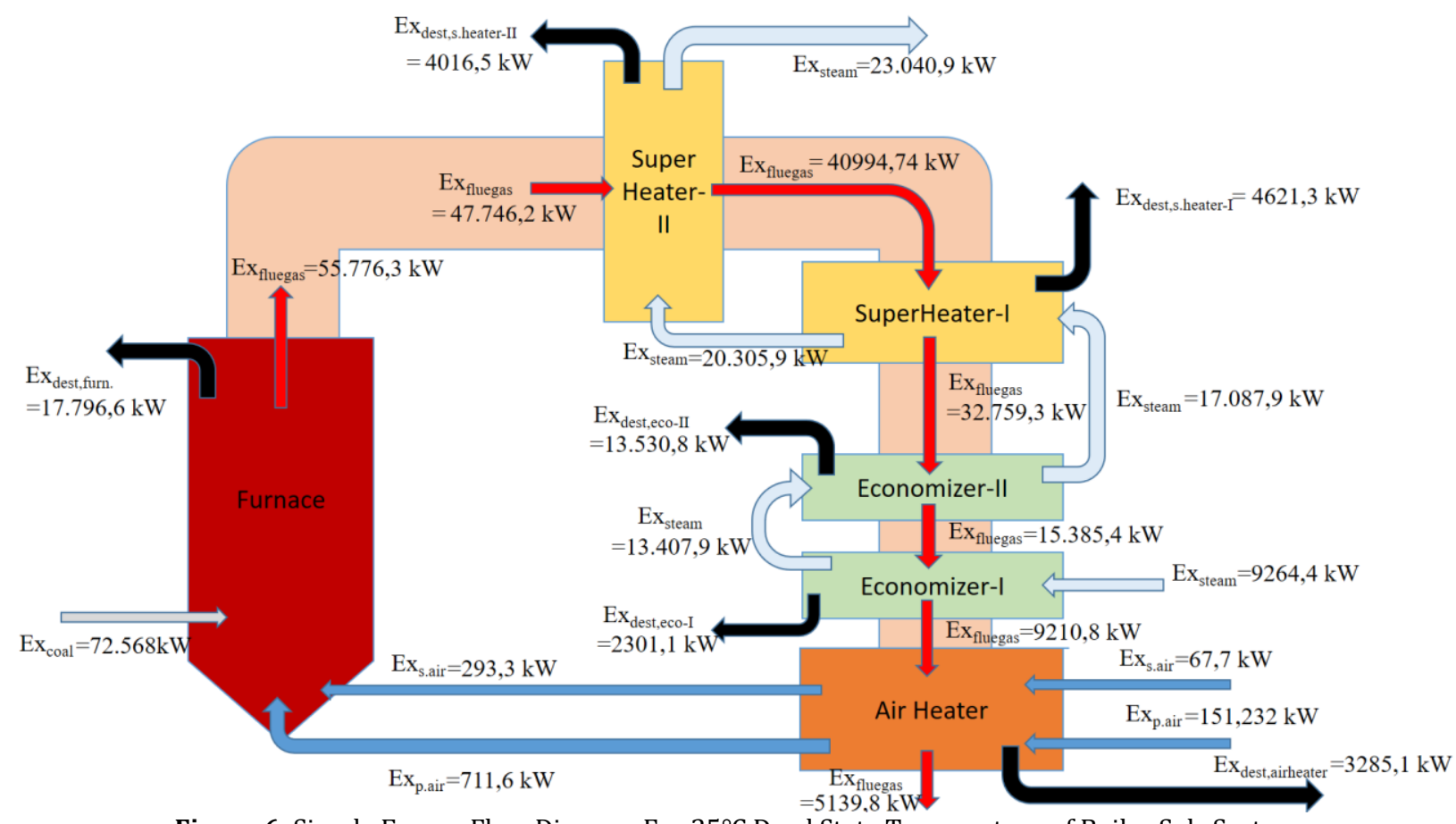

Figure 6. Simple Exergy Flow Diagram For $25^{\circ} \mathrm{C}$ Dead State Temperature of Boiler Sub-Systems

\section{Conclusions}

In this study, a circulation-type fluidized bed boiler's exergy performance in a power generation plant was investigated. The boiler was examined not as a whole but by dividing it into its sub-systems. In the analysis, the sub-systems' exergy performance was evaluated in terms of criteria such as exergy efficiency, exergy destruction, fuel depletion rate, relative exergy destruction, exergetic improvement potential, and productivity lack rate. Also, the effect of different dead state temperatures on these exergy performance criteria was compared and discussed. The results obtained are listed below.

- The highest exergy efficiency was realized in the furnace at $6^{\circ} \mathrm{C}$ with $80.2 \%$. The lowest exergy efficiency was realized in the air heater at $27^{\circ} \mathrm{C}$ with $18.9 \%$. While the exergy efficiency of superheater-I, economizer-I, and economizer-II increased with the increase in the dead state temperatures, it decreased in the furnace, air heater, and superheater-II.

- The highest exergy destruction occurred in the furnace with $18,118.9 \mathrm{~kW}$ at $27^{\circ} \mathrm{C}$, the lowest in the economizerI with $1968.4 \mathrm{~kW}$ at the same temperature. With the increase in the dead state temperature, only the exergy destruction that occurred in the furnace increased, while the other parts decreased.

- The highest exergetic improvement potential was realized in the economizer-II with $11,593.82 \mathrm{Kw}$ at $6^{\circ} \mathrm{C}$. The lowest value, on the other hand, was $131.9 \mathrm{~kW}$ at $27^{\circ} \mathrm{C}$ in economizer-I.

- The productivity lack was highest in the furnace at $27^{\circ} \mathrm{C}$ with $25.7 \%$. The other highest productivity lack occurs in economizer-II, while other parts are lower than these two components.

- In the fuel depletion rate criterion, the highest value was at $15.6 \%$ in the furnace at $27^{\circ} \mathrm{C}$, and the lowest was in the economizer-I at the same temperature.

- Depending on the increase in the ambient temperature, relative exergy destruction and exergetic improvement potential only increased in the furnace, while other parts decreased. There was an increase in the furnace and superheater-II for the fuel depletion ratio and a decrease in the other parts. For the productivity lack, the increase in ambient temperature showed its effect as an increase in the furnace, superheater-I, and superheater-II, and a decrease in the other parts.

- As a result, although the highest efficiency happened in the furnace, the highest exergy destruction happened in this part. In addition, the highest exergetic development potential was realized in economizer-II. If improvement work is to be done to increase efficiency in the boiler, priority can be given to the economizer-II part. 


\section{Conflict of Interest}

No conflict of interest was declared by the authors.

\section{References}

Akkurt, F., Kahraman, A., 2017. An Exergy Analysis of Solar-Assisted Ejector Cooling System for Different Area Raatios at Their Maximum COP Values. Thermal Sciences, 23, 179-190.

Aljundi, I.H., 2009. Energy and Exergy Analysis of A Steam Power Plant in Jordan. Applied Thermal Engineering, 29, $324-328$.

Balli, O., Aras, H., Aras, N., Hepbasli, A., 2008. Exergetic and Exergoeconomic Analysis of An Aircraft Jet Engine. International Journal of Exergy, 5, 567-581.

Behbahaninia, A., Ramezani, S., Hejrandoost, M.L., 2017. A Loss Method for Exergy Auditing of Steam Boilers. Energy, 140,253260.

Callak, M., Balkan, F., Hepbasli, A., 2015. Avoidable and Unavoidable Exergy Destructions of A Fluidized Bed Coal Combustor and A Heat Recovery Steam Generator. Energy Conversion and Management, 98, 54-58.

Çengel, Y.A., Boles, M.A., 2008. Thermodynamics on Engineering Approach (6 $6^{\text {th }}$ Edition) page 445 ISBN 978-0-07-125771-8

Dincer, I., Rosen, M.A., 2007. Exergy, Energy, Environment and Sustainable Development. Elsevier

Elhelw, M., Dahma, K.S., Attia, A., 2019. Utilizing Exergy Analysis in Studying the Performance of Steam Power Plant at Two Different Operation Mode. Applied Thermal Engineering, 150, 285-293.

Erdem, H.H., Akkaya, A.V., Cetin, B., Dagdas, A., Sevilgen, S.H., Sahin, B., Teke, I., Gungor, C., Atas, S., 2009. Comparative Energetic and Exergetic Performance Analyses for Coal Fired Thermal Power Plants in Turkey. International Journal of Thermal Sciences, 48,2179-2186.

Eskin, N., Kilic, A., 1996. Estimation of Cooling Tube Location in Fluidized Bed Coal Combustors Through Exergy Analysis. Energy Conversion and Management, 37 (9), 1453-1461.

Eskin, N., Gungor, A., Özdemir, K., 2009. Thermodynamic Analysis of A FBC Steam Power Plant. Energy Conversion and Management, 50, 2428-2438.

Ganapathy, T., Alahumurthi, N., Gakkhar, R.P., Murugesan, K., 2009. Exergy Analysis of Operating Lignite Fired Thermal Power Plant. Journal of Engineering Science and Technology Review, 2 (1), 123-130.

Gürtürk, M., Oztop, H.F., 2016. Exergy Analysis of A Circulating Fluidized Bed Boiler Cogeneration Power Plant. Energy Conversion and Management, 120, 346-357.

Hepbasli, A., 2009. Exergetic Modeling of Oil Shale-Fired Circulating Fluidized Bed Systems. Energy Sources, Part A: Recovery, Utilization, and Environmental Effects, 31:4, 325-337.

İpek, O., Kılıç, B., Gürel, B., 2017. Experimental Investigation of Exergy Loss Analysis in Newly Designed Compact Heat Exchangers. Energy, 124, 330-335.

Kolip, A., Savas, A.F., 2010. Energy and Exergy Analyses of A Parallel Flow, Four-Stage Cyclone Precalciner Type Cement Plant. International Journal of The Physical Sciences, 5 (7),1147-1163.

Kopac, M., Hilalci, A., 2007. Effect of Ambient Temperature on The Efficiency of The Regenerative and Reheat Çatalağzı Power Plant in Turkey. Applied Thermal Engineering, 27, 1377-1385.

Li, Y., Liu, L., 2012. Exergy Analysis of 300 MW Coal Fired Power Plant. Energy Procedia, 17, 936-932.

Ozdil, N.F.T., Tantekin, A., Erbay, Z., 2016. Energy and Exergy Analyses of A Fluidized Bed Coal Combustor Steam Plant in Textile Industry. Fuel, 183, 441-448.

Pattanayak, L., Sahu, J.N., 2015. Steady State Modeling on Energy and Exergy Analysis of A Pulverized Coal Fired Thermal Power Plant. Asia-Pacific Journal of Chemical Engineering, 10, 876-884.

Regulagadda, P., Dincer, I., Naterer, G.F., 2010. Exergy Analysis of Thermal Power Plant with Measured Boiler and Turbine Losses. Applied Thermal Engineering, 30, 970-976.

Sengupta, S., Datta, A., Duttagupta, S., 2007. Exergy Analysis of Coal Based 210 MW Thermal Power Plant. International Journal of Energy Research, 31, 14-28.

Sharma, M., Singh, O., 2016. Exergy Analysis of Dual Pressure HRSG for Different Dead States and Varying Steam Generation States in Gas/Steam Combined Cycle Power Plant. Applied Thermal Engineering, 93, 614-622.

Si, N., Zhao, Z., Su, S., Han, P., Sun, Z., Xu, J., Cui, X., Hu, S., Wang, Y., Jiang, L., Zhou, Y., Chen, G., Xiang, J., 2017. Exergy Analysis of A 1000 MW Double Reheat Ultra-Supercritical Power Plant. Energy Conversion and Management, 147, 155-165.

Suresh, M.V.J.J., Reddy, K.S., Kolar, A.K., 2011. Thermodynamic Analysis of A Coal Fired Power Plant Repowered with Pressurized Pulverized Coal Combustion. Proc. IMecE. Vol. 226 Part A: J. Power and Energy, 1-12.

Szargut, J., Morris, D.R., Steward, F.R., 1988. Exergy Analysis of Thermal, Chemical, and Metallurgical Processes. New York: Hemisphere.

Szargut, J., 2005. Exergy Method: Technical and Ecological Applications. Southampton (UK): WIT Press

Şöhret, Y., Açıkkalp, E., Hepbasli, A., Karakoc, T.H., 2015. Advanced Exergy Analysis of An Aircraft Gas Turbine Engine: Splitting Exergy Destructions into Parts. Energy, 90, 1219-1228.

Topal, H., Taner, T., Naqvi, S.A.H., Altınsoy, Y., Amirabedin, E., Ozkaymak, M., 2017. Exergy Analysis of A Circulating Fluidized Bed Power Plant Co-Firing With Olive Pits: A Case Study of Power Plant in Turkey. Energy, 140, 40-46.

Van Gool, W., 1992. Exergy Analysis of Industrial Processes. Energy, 17,791-803.

Wang, N., Wu, D., Yang, Y., Yang, Z., Fu, P., 2014. Exergy Evaluation of A 600 MWe Supercritical Coal-Fired Power Plant Considering Pollution Emissions. Energy Procedia, 61, 1860-1863.

Wu, L., Wang, L., Wang, Y., Hu, X., Dong, C., Yang, Z., Yang, Y., 2014. Component and Process Based Exergy Evaluation of A 600 MW Coal-Fired Power Plant. Energy Procedia, 61, 2097-2100

Xiang, J.Y., Cali, M., Santaralli, M., 2004. Calculation for Physical and Chemical Exergy of Flows in Systems Elaborating MixedPhase Flows and A Case Study in An IRSOFC Plant. International Journal of Energy Research, 28, 101-115. 
Xiong, J., Zhao, H., Zheng, C., 2011. Exergy Analysis of A 600 MWe Oxy-Combustion Pulverized-Coal-Fired Power Plant. Energy and Fuels, 25, 3854-3864.

Yazıcı, M., Köse, R., 2019. Çevre Sıcaklığının Dolaşımlı Akışkan Yataklı Kazanın Ekserji Performansı Üzerindeki Etkisi. Bilecik Şeyh Edebali Üniversitesi Fen Bilimleri Dergisi, 6 (2), 477-490.

Zhang, Q., Yi, H., Yu, Z., Gao, J., Wang, X., Lin, H., Shen, B., 2018. Energy-Exergy Analysis and Energy Efficiency Improvement of Coal-Fired Industrial Boilers Based on Thermal Test Data. Applied Thermal Engineering, 144, 614-627.

Zhou, J., Ling, P., Su, S., Xu, J., Xu, K., Wang, Y., Hu, S., Zhu, M., Xiang, J., 2019. Exergy Analysis of A 1000 MW Single Reheat Advanced Supercritical Carbon Dioxide Coal-Fired Partial Flow Power Plant. Fuel, 255, 115777. 